\title{
The Developing a Pictured Story Book as Emotional Intelligence for Low Grade Elementary School Students
}

\author{
Rima Hazrati ${ }^{1}$, Susi Fitri' ${ }^{1}$, RA. Murti Kusuma Wirasti ${ }^{1}$ \\ ${ }^{1}$ Masters in Guidance and Counseling, Universitas Negeri Jakarta, Indonesia \\ rimahazrati_bk17s2@mahasiswa.unj.ac.id; susi.fitri@unj.ac.id; murti@unj.ac.id \\ ${ }^{*}$ Corresponding Author
}

How to Cite : Hazrati, R., Fitri, S., Wirasti, R., M., K. (2020). The Developing a Pictured Story Book as Emotional Intelligence for Low Grade Elementary School Students. International Journal for Educational and Vocational Studies, 2 (1), 50-52. DOI: https://doi.org/10.29103/ijevs.v2i1.1962

\section{ARTICLE HISTORY}

Received:14 October 2019

Revised: 20 December 2019

Accepted: 26 January 2020

\section{KEYWORDS}

Development;

Illustrated Story Book;

Emotional Intelligence;

Elementary School Students;

\begin{abstract}
This study uses a type of research \& development method or in English (Research and Development) terms. The development model in the study uses the Borg and Gall model, where this model comes from the results of thought, is still a concept that is empirically tested and its implementation organized from planning, implementation to evaluation of the results. The purpose of this study is to produce a product that is a picture story book about emotional intelligence that meets the criteria of feasibility aspects. Emotional intelligence should begin to be developed as early as possible because it can make children have high enthusiasm in learning or liked by their friends in the playground. The development of this illustrated storybook uses components or dimensions of emotional intelligence from Daniel Goleman. There are 5 dimensions that will be used for 5 themes in illustrated storybooks namely self-awareness, self-regulation, motivation, empathy, social skills. The form of the book that will be created with hard cover and will be dominated by images. The goal of developing this storybook media is aimed at lower primary school students, which are around the ages of 6 to 9 years.
\end{abstract}

This is an open access article under the CC-BY-SA license.

\section{INTRODUCTION}

In education, educational model largely just focused on intellectual development. As a result, there was a gap between the development of intellectual intelligence and emotional intelligence and produce various negative behavior of students (Poerwanti, 2005). There were some cases at all levels of education level. Such cases of stealing, ditching, Brawling, bullying, even to the murdering case. Ironically, it happened in Primary school students. It can be caused due to the low emotional intelligence of individuals. Negative behavior associated with low value an individual emotional intelligence (Petrides and Sangareau, 2006).

Emotional intelligence should start to be developed as early as possible because it can make the children to be more passionate in learning or favored his friends on the playground. By having emotional intelligence as early as possible, it can help a person entering the workforce or when raised a family in the future. In addition, emotional intelligence also played an important role in our relationships with others as well as with the creator, so that our children are able to appreciate himself, others and especially that created him in Nur Hayati (2013). Emotional intelligence is considered as important in education as it affects students in the process of teaching and learning. Quoted from research Rika (2013) that basically children who experienced emotional turmoil, will certainly have difficulty to think clearly. This will result to a decline in the effectiveness of learning, because children who are restless, anxious or restless would not be able to think properly. Thus, knowing the child's emotional intelligence earlier is needed to support their success in school.

Emotional intelligence can be developed through many things. As revealed in Research Prima (2017) that the role of emotional intelligence is important for children's life so that required the presence of the stimulus in order to develop optimally like games, storytelling, acting, drawing, and so on. Storytelling is one the way to increase emotional intelligence. But there should be a medium to support the process of storytelling. Such as picture story book media, which can assist or facilitate educators to tell stories with the theme of 
emotional intelligence. Based on the results of research on emotional intelligence can be improved through reading picture story book (Atik, 2012). So children can increase emotional intelligence of his use of picture story book media.

This is supported by Pratiwi (2017) research who said that the characteristics of Primary school children include narrative thinking, and high of curiosity. One of the activities they enjoy is listening to stories. Besides, the characteristics of lower primary school age children are operational concrete, children like stories, and narrative thought. In the community itself interactive picture story books with the theme of emotional intelligence are hard to find. The use of interactive concepts is to make the target audience who at the age of golden age absorbs and remembers what is said in the book well, because children have the ability to remember pictures or activities that they do well (Mercia, 2014).

The use of media can be one of the tools for teachers to be able to teach about emotional intelligence in children. Then the teacher can use props and visual, audio, audio-visual, and other medias. Based on observations on children aged 6-8 years in elementary school, researchers observed that the learning method emphasized the lecture method more, teachers still use worksheets and blackboards. The atmosphere of learning in the classroom becomes monotonous and less attractive to children.

The specific area of this study refers to the field of guidance and counseling, namely the Personal field. In accordance with the standards of independence of students in primary school in the aspect of development of emotional maturity which has the goal of knowing the feelings of yourself and others, understanding the feelings of yourself and others, expressing feelings naturally. Based on the background of the problems that have been described, the researchers feel scientific study through research on the development of illustrated storybook media on the emotional intelligence of lower primary school students is needed.

\section{METHODS}

The researcher uses a type of development research or in English (Research and Development) terms. Sukmadinata (2012: 297) states that "Research and Development (Research and Development R \& D) is a process or steps to develop a new product or improve existing products, which can be justified". According to Gay, Mills, and Airasian (in Emzir, 2015: 263)"In education, the aim of research and development is not to formulate or test theories, but to develop products that are effectively used in schools". The development model in the study uses the Borg and Gall model, which this model comes from the results of thought, still a an empirically tested concept and its implementation organized from planning, implementation to evaluation of the results.

In $\mathrm{R} \& \mathrm{D}$ research conducted by researchers, it will produce Design of illustrated Story Book Media of
Emotional Intelligence for low primary school students.

\subsection{Development Procedure}

The stages of making or developing illustrated Story Book Media of Emotional Intelligence for low primary school students refers to the $4 \mathrm{D}$ development model (four D models) by S. Thigarajan, Dorothy S. Semmel, and Melvyn I. Semmel. Mulyatiningsih (2011: 179) describes the stages of research and development using the 4D model, as follows:

1) Define

2) Design

3) Development

4) Dissemination

Because the results of this study will not be disseminated to other Agencies/Institutions (other than research sites), So only three stages used until the development stage. This is because researchers only focus on design and concepts.

\section{RESULTS AND DISCUSSION}

Emotional intelligence is the ability to recognize one's own feelings and the feelings of others the ability to motivate themselves, and the ability to manage emotions well in themselves and in building relationships with others. Emotional intelligence should begin to be developed as early as possible because it can make children have high enthusiasm in learning or liked by their friends in the playground.

In this study, the media will develop illustrated storybooks about emotional intelligence. The following is the design of "Picture Story Media Emotional Intelligence Book": At this stage, first make an initial draft of the media that includes media design, contents of book material, characters used. The content of the material in this storybook is about aspects of emotional intelligence, namely self-awareness, self-regulation, motivation, empathy, social skills.

This research is still in the early stages of design and concept. Based on the results above, researchers will continue to develop a picture story book media that will help students because it affects students' personalities in the teaching and learning process. With the media picture book, it is expected to be able to add information and understand students about emotional intelligence more easily and interactively, because in this book using animated images that make students interested in using and expected students to be motivated to apply in everyday life.

\section{CONCLUSION}

Emotional intelligence should begin to be developed as early as possible because it can make children have high enthusiasm in learning or liked by their friends in the playground. The phenomenon in schools is that there are 
many students who cannot control their emotions or be aggressive, such as being rude to others, often quarreling, getting along with troubled children, stubborn at home and at school, stubbornness and mood swings, too much talk, often make fun and have high temperament. Education does not have to go through school but can also be outside of school. Knowledge about emotional intelligence can be obtained from the family environment and also peers. How parents introduce emotional intelligence to their children. With the media picture book, it is hoped that it can help students understand students emotional intelligence and apply it into daily life.

\section{REFERENCES}

Anggara, Mercia Berlin. (2014). Perancangan Buku Cerita Bergambar Interaktif Pendidikan Karaker Untuk Anak Usia 4-6 Tahun. Jurnal DKV.

Emzir. (2010). Metodologi Penelitian Pendidikan:Kuantitatif dan Kualitatif. Jakarta: Rajawali Pers.

Goleman, Daniel. (2003). Kecerdasan Emosi untuk Mencapai Puncak Prestasi.Terjemahan: Alex Tri Kantjono, Jakarta: Gramedia Pustaka Utama ,

Hanifah, T. U. (2014). Pemanfaatan Media Pop-Up Book Berbasis Tematik untuk Meningkatkan Kecerdasan Verbal-Linguistik Anak Usia 4-5 Tahun (Studi Eksperimen di TK Negeri Pembina Bulu Temanggung). BELIA: Early Childhood Education Papers, 3(2).

Hayati, N. (2008). Menstimulasi Kecerdasan Emosional Anak Sejak Usia Dini. FONDASIA, 1(9).

Indarwati, Agustin. (2012). Upaya Meningkatkan Kemampuan Berbahasa Lisan Dengan Menggunakan Media Cerita Bergambar Pada Anak Kelompok B Di Tk Aisyiyah 44 Tandes Lor Kota Surabaya.

Kawuryan, Sekar. (2011). Karakteristik Siswa Sd Kelas Rendah Dan Pembelajarannya. PPSD FIP UNJ

Lestari, M. A., Erlianti, M., \& Permana, A. (2017). Efektivitas Penggunaan Media Buku Cerita Bergambar dalam Penanaman nilai-nilai Moral Siswa SD Kelas Rendah. Pedagogi: Jurnal Penelitian Pendidikan, 4(2).

Mulyatiningsih, E. (2012). Metode Penelitian Terapan Bidang Pendidikan. Yogyakarta: Alfabeta.

Nurhaida, I., Hariyanto, S. P., Junaidi, A., \& Syah, P. (2007). Merancang Media Hiburan Buku Cergam Menjadi Media Belajar untuk Alat Bantu Komunikasi. Mediator: Jurnal Komunikasi, 8(1), 51-64.

Petrides, K. V., Sangareau, Y., Furnham, A., \& Frederickson, N. (2006). Trait emotional intelligence and children's peer relations at school. Social Development, 15(3), 537-547.
Poerwanti, E. 2005. Memahami Pertumbuhan Kecerdasan Intelektual dan Kecerdasan Emosional Anak untuk Kepentingan

Pendidikan. www.malang.ac.id/jurnal/fip/sd/-8k.

Pratiwi, N. L. M. T. (2017). Pengembangan buku cerita anak dengan menginsersi budaya lokal dalam tema kegemaranku untuk kelas i sekolah dasar. Jurnal Imiah Pendidikan dan Pembelajaran, 1(3).

Prima, E. (2017). Pengembangan Kecerdasan Emosional Anak Melalui Game DOTA (Defence of The Ancients). KOMUNIKA: Jurnal Dakwah dan Komunikasi, 11(1), 149-165.

Rosari, Y. P. P., Agung, A. A. G., Ambara, D. P., \& Psi, S. (2014). Penarapan Metode Bercerita Berbantuan Media Buku Cerita Bergambar Untuk Meningkatkan Perilaku Moral. Jurnal Pendidikan Anak Usia Dini Undiksha, 2(1).

Rahmatika, A. N. (2015). Pengembangan Media Buku Bergambar Perilaku Asertif Untuk Siswa Kelas IV Sekolah Dasar. Jurnal Mahasiswa Bimbingan Konseling UNESA, 5(3).

Sa'diyah, R. (2013). Melatih Kecerdasan Emosi Anak Usia Dini. INSANIA: Jurnal Pemikiran Alternatif Kependidikan, 18(1), 117-134.

Santoso, T., Harpawati, T., \& Prihartanti, N. (2009). Mendidik Tanpa Menggurui melalui Dongeng Anak. Gelar: Jurnal Seni Budaya, 7(2).

Sukmadinata, N. S. (2012). Metode Penelitian Pendidikan, PT Remaja Rosdakarya. 